\title{
Situative governance and energy transitions in a spatial context: case studies from Germany
}

\author{
Gerhard Fuchs ${ }^{*}$ and Nele Hinderer
}

\begin{abstract}
While the traditional form of electricity generation and supply is based on centralized structures with large-scale power plants, the objective of a strongly decentralized form of energy supply is increasingly becoming of importance. Sustainability-oriented energy transitions are relying on various sorts of renewable energies coupled with energy efficiency initiatives. In the current existing regulatory and market frameworks in Germany and elsewhere, important technical and institutional innovations for energy transitions were and are being developed, tested, and brought to application on regional and local levels. Regions, cities, and villages experimenting with socio-technical innovations and aiming to implement new concepts have to develop governance structures under high uncertainty. These governance structures mirror space-specific social, political, technological, and economic constellations. The present paper introduces an analytical approach for studying emergent forms of governance and uses four cases from Germany to apply the approach. Research is based on a comparative case study research design, using primarily expert interviews and document analysis as data sources. The cases demonstrate that sustainable energy transitions are driven forward by a variety of actors with different aims and interests, culminating in the development of space-specific technological mixes and situative governance structures. Sustainable energy transitions are not following a master plan or are coordinated on a national level. The upper political levels and external events pose severe constraints for the implementation of local transition initiatives. Future research should further aim to highlight and analyze the contentious character of local energy transitions.
\end{abstract}

Keywords: Sustainable energy transitions; Germany; Electricity supply; Local initiatives

\section{Review}

Introduction

While the traditional form of electricity generation and supply is based on centralized structures with large-scale power plants, the objective of a strongly decentralized form of energy supply is increasingly becoming of importance. In the current existing regulatory and market frameworks in Germany and elsewhere, important technical and institutional innovations for sustainable energy transitions were and are being developed, tested, and brought to application on regional and local levels. Regions, cities, and villages experimenting with socio-technical innovations and aiming to implement new concepts have to develop governance structures under high uncertainty ${ }^{\mathrm{a}}$. These governance arrangements, which have yet to be tested for their persistence

\footnotetext{
* Correspondence: Gerhard.fuchs@sowi.uni-stuttgart.de

Institute for Social Sciences, University of Stuttgart, Seidenstr.36, Stuttgart 70174, Germany
}

(c) 2014 Fuchs and Hinderer; licensee Springer. This is an Open Access article distributed under the terms of the Creative

and functionality, mirror space-specific social, political, technological, and economic constellations [1].

In this context, the article analyzes the development of decentralized situational governance as a basis for innovation impulses for the sustainable transformation of the electricity system in Germany. Assuming that local, urban, and regional governance structures develop in conflict with the established structures of the field 'electricity generation', the article analyzes a range of German initiatives as 'strategic action fields', within which socio-technical innovations are being developed. Based on the recent theory by Fligstein and McAdam [2,3], the paper stresses the importance of the actions of so-called challenger actors, which eventually might contribute with their activities to a change in the overall system of electricity generation. The article thus treats the city or any local entity not as a given unit, but looks at the actors or coalition of actors who want to change existing structures. They are challenging the established status quo. \\ Springer}


Local, urban, and regional initiatives are often interpreted in the literature as small experimental 'niches': constrained, but also enabled, by wider social and political structures and developments [4]. Niche innovations may lead nowhere, or even serve to reinforce the status quo. Equally, however, they can have far wider implications as well. Implications are hard to predict in advance, since they are dependent on new cognitive frames, changing economic and political power constellations and innovative measures to become effective. Insofar, it is of eminent importance to look at the actors and their resources, their position within the field under investigation for evaluating their actions, and their potential contribution to a transformation of the electricity system towards more sustainability. The article will look more closely at four cases and ask what actors are present in the fields and what the dominant lines of conflict they are engaged in look like. Energy transitions are concerned with the change of established structures and institutions. Change has to be brought forward by skilled actors, forming coalitions and developing innovative policies, which eventually will bring about new institutions more favorable for the realization of sustainability aims.

The article will proceed as follows. The 'Transition and its driver' section looks at the question what actors are driving transition processes and will identify ways to analyze their status. It is primarily discussing to what extent it can be assumed that transition impulses will be initiated by incumbent or regime actors. This is followed by a discussion of important trends of decentralization in the German system of electricity generation ('Electricity transitions in Germany' section). The section addresses the question what types of decentralized impulses we are dealing with. The 'Cases of $100 \%$ bio regions' section introduces four cases in more detail followed by an analysis of important lines of conflict the local initiatives are engaged in ${ }^{\mathrm{b}}$.

\section{Transition and its driver}

The fact that local and urban governments are increasingly adopting energy-related policies that aim at a transformation of the electricity supply system is widely acknowledged [5]. Nevertheless, the relevance of the spatial scale of these initiatives until recently remained often implicit or underdeveloped in transition approaches [6]. This negligence might have two reasons: on the one hand, sociological approaches do have the tendency to underrate the role of physical spatial proximity, because they usually assume that closeness in social space is paramount. On the other hand, a lot of the transition literature is explicitly technology oriented and takes as its point of departure a specific technology and studies its pathway towards success or failure, being more oriented towards analyzing institutional elements of technological innovation systems then the actual, process-related conditions of institutional development. Regions and local communities are usually considered more passively as seedbeds, but not as originators of powerful transition-oriented initiatives. This, however, need not be the case. The example of the development of solar technology in Germany has amply shown that the initiative for experimenting with and developing this technology came from certain local and/or regional pockets in opposition to developments on a more central level, be it the federal or state government or the incumbent actors in the field of electricity supply [7].

Studies based on the multi-level perspective [8-10] identify dynamic processes, which are characterized by the existence of path dependencies and lock-in phenomena as well as by interdependencies between technical and social change processes [11-13]. Trajectories of persistence thereby hinder change and are hence essential for analyzing the reluctant withdrawal from fossil path dependencies. But there is an acknowledged lack of actor orientation, as well as comparatively few studies on areafocused strategies and innovation resources [14,15]. Even though the innovation niches which are in the focus of analytical works were attributed to local characters, the spatial embedding of innovation processes and the dynamics of innovation there, negotiation processes, and the 'battle of the systems' is neglected $[5,16]$.

Looking at the way local initiatives organize, bringing about what we will call situative governance, forces us to engage with the driving forces aiming to create a new governance structure. Insofar, we look at the 'roots of local policy responses to climate change' [17]. One line of thinking stresses the role of incumbent actors in initiating transition processes especially on the local level. Smith et al. [18] argue that there would be a need to further develop regime endogenous transition perspectives, where the transition process is conceptualized as the result of incumbent regime actors (local/urban governments) making conscious and planned efforts in response to perceived pressures using regime-internal resources. We take issue with this approach. It is a theoretical as well as an empirical question to identify and categorize the actors responsible for bringing forward initiatives towards transformation or a transition of a regime or the dominating rules within a field.

We suggest looking at field theory, which is interested in studying institutional change and stability. The theory sees fields as the fundamental units of collective action in society. Fields are constructed by actors who are pursuing specific aims. Stable fields are characterized by the fact that the main actors are able to reproduce themselves over longer periods of time, while in unstable fields, understandings about what the field is all about and who has power and why are contested. Defenders of 
the status quo are called incumbents, and those engaged in conflict with them are challengers. It is important to note that the social structure of a field is always related to a common problem with which the actors are concerned. In order to identify who is incumbent and who is the challenger, it is therefore first of all necessary to identify what the field is all about. The field of electricity generation is dominated by the actors responsible for this task, and there are rules that regulate who under what conditions is allowed to do what as well as there are implicit rules concerning what the actors consider to be legitimate actions. So for example, the big energy providers in Germany for a long time did not venture into territory that was supposed to belong to a fellow energy provider. Insofar, the four big German energy providers still are regionally concentrated, and the market is generally divided up between them.

The theory of strategic action fields [2,3] claims to be able to answer the question, how and under what conditions relatively powerless actors are able to mobilize and (re)organize fields, in our case, electricity supply infrastructures. It helps us to analyze the actions of challenger actors on a local level, which eventually might contribute to a change in the overall system. As outlined above, the theory claims that usually an incumbent-challenger structure is present, if aims in a field are contested. It further claims that incumbents will be usually interested in defending the status quo, while challengers will try to inflict damage on the incumbents and try to change the status quo. The theory (as well as the many empirical studies that have been done in the institutionalist tradition) would not make us expect that incumbents are eager to significantly change the structures of the field from which they benefit or that they would in fact be the drivers for creating a sustainable urban regime adjustment.

In my mind, the debate about the role of incumbents in transition processes can be solved analytically. Many case studies stress the role of mayors or city councils in developing plans for sustainability and energy transitions. Observers sometimes consider them the incumbents, because they possess at a specific moment a political powerful position. State actors or political actors, however, are usually not competing in the field under investigation proper, e.g., electricity supply. They are on the outside trying to regulate the field. The field of electricity supply is populated by the actors responsible for providing energy. Political decision makers then and there concern themselves with energy questions, but are not routinely involved in the business. If the system of energy provision changes due to new political decisions, this is the result of bargaining mainly between politicians and very often the result of changing majorities. If the mayor or city council wants to change the energy system, she has to engage with the incumbent actors in the field who will usually try to resist changes that would result in a change of their status. This differentiation is useful to make, because it sheds light on the different games actors play and the different logics that drive the activities of actors [19]. Mobilizing a community and generating electricity at market prices are two different things that can influence each other but are following different logics.

Quitzau et al. claim that an '... endogenous perspective suggests a need for more institutionally entrenched transition typologies' [20]. This argument is well taken, but there seems to be no need to take the supposedly transforming actions of incumbent actors as the starting point for further developing transition-oriented typologies. Regimes in this context need not be considered as something being solely restrictive. Regimes also have an enabling role. Without regimes and the security for decision-making they offer to both private and public actors, a lot of activities would not be happening or would be frustrated due to a lack of perspective. For example, the development of renewable energies in Germany could only take off once there was something like a regime that made it possible for the relevant actors to make decisions reaching into the future.

This implies that regimes without any doubt are characterized by a certain stability (dominant actors, rules, cognitive frames, and legitimate actions), but that does not mean that only uniform behavior can be observed. Regime actors are of course constantly adapting to new circumstances; they are trying to keep their position even when faced with a turbulent or threatening environment. Thus, slight changes in the strategies of incumbent actors are quite a normal incidence. They are not threatening the regime but strengthening it.

The claim that transition theory underrates '... the potential of incumbent regime actors as orchestrators of transitional change. By means of their skills in situated interpretations and creativity, such actors may also use regime rules to consciously modify traditional patterns of associations among flows of socio-technical systems' [20] has to be seen in this light both as a theoretical claim, for which we see no justification ${ }^{c}$ as well as an empirical claim, which of course can be verified or falsified. We will further explore our argument about the importance of the social structure of fields and the position of actors within the field by looking at an important recent contribution to the transition discussion.

Hargreaves et al. [21] have highlighted the role of intermediaries for local and regional projects. In fact, organizing and having organizational support are crucial for a project to be successful, and if an ongoing project aims to have a broader impact, de-localized forms of organization have to be found. Hargreaves et al. [21] stress that along with the growing maturity of local innovation projects, the role of intermediaries increases, which is sensible given 
that local initiatives develop knowledge and successful projects will have to take into account available knowledge. On the other hand, many projects are embedded in programs, support schemes, etc. and do not have only a local or regional aim but intend to have a larger impact on the whole system of electricity generation or even how the architecture of the society as a whole should look like. Insofar, it seems more than reasonable to suggest that new professionalized knowledge gradually develops, with its own set of specialists and more general ideas about how things are best done. In the terminology of sociological neo-institutionalism, we can detect processes of isomorphism.

The authors furthermore stress the specifics of local innovation projects (in contrast to market-oriented projects). In our mind, however, the difference should not be seen in the local character of the initiatives as such, but in the uncertainties surrounding their activities as they are challenging the incumbents. The authors (a) rightly stress that local initiatives show an amazing breadth of distinct organizational forms. A broad range of organizational types encompassing cooperatives, voluntary associations, informal community groups, etc. can be found. It has to be added, however, that local initiatives might also create companies, and entrepreneurial people are wary about the organizational form that best suits their ambitions. (b) Furthermore, there are different resource bases: voluntary labor, grant funding, etc. This can also be claimed for new firm foundations in the electricity sector, which especially in the founding phase very often depend on grants, personal, or family resources and have a hard time making ends meet. On the other hand, both local initiatives as well as companies in the end have to generate some kind of income and are equally resource dependent. (c) There are important divergent contextual situations, which is equally true for firm foundations as well as local initiatives. In addition, the authors claim that (d) there are alternative driving motivations: meeting social needs, pursuing ideological commitments. An entrepreneur in the field of electricity generation might be driven by the same motives. Again, we can see this when looking at the development of the renewables industry in Germany, where political and social motives were decisive for the development of the industry. On the other hand, local initiatives can aim to generate profits as many of the German examples we have studied demonstrate.

Hargreaves et al. [21] thus underestimate the common problems private as well as public actors face when they are in a situation of challenging the status quo: (a) Both are unsure about the contours of the future regulatory development. (b) Local initiatives as well as new companies are working with technologies or technology mixes and intend to offer services linked to specific technological developments; the viability of which on the long run still needs to be proven. New technology developments (e.g., in the field of energy storage technologies) or regulatory developments may delegitimize plans. (c) Just like firms, local initiatives have to be organized, structured, and made to work. Finally, (d) local initiatives just like companies have to do something useful and legitimate in the eyes of their (potential) clients. Challengers in the field of electricity generation generally have to cope with a fluid institutional framework.

\section{Electricity transitions in Germany}

An important line of conflict between incumbent and challenger actors in the electricity system relates to the extent to which it will have a decentralized architecture. This is not a purely technological problem. Renewable energies could also be harvested and run in a more centralized manner by using big solar farms and huge (off shore) wind parks, administered, e.g., by the established big energy providers. This could also be called sustainable. However, most actors on the local level are inspired by the idea that electricity generation should be dramatically decentralized in both technological as well as organizational form. This is not only a German discussion. Many urban and local governments worldwide are working on reconfigurations of local energy systems [22]. Germany, without any doubt, is among the countries with an especially wide variety of relevant initiatives. This might appear surprising at first. The German electricity system used to be characterized by strong local and regional monopolies, but after the liberalization of energy markets in the late 1990s, these supposedly inefficient structures were replaced by an oligopolistic system run by four big energy providers (ENBW, E.ON, Vattenfall, and RWE), which had divided the market among themselves along regional lines. In the process of liberalization, there was a clearly stated political will by actors from the state and national levels to create powerful and supposedly competitive big actors. The four energy providers therefore were gulping up smaller competitors by various means. They built their strength on the provision of a standardized good 'electricity', which is mainly produced in big power stations owned by them and running on fossil fuels or nuclear power. Insofar, the developments in the 1990s and in the early years of the new millennium were largely characterized by a process of concentration and centralization.

Somewhat independent from these developments, however, individual concerned scientists and citizens, later on local governments, were developing alternatives to the dominant centralized structures. They were relying especially (but not exclusively) on renewable energies and were bypassing the incumbent regime. In the beginning, small individual sites, in the case of PV, e.g., individual homes were transformed into sites of electricity generation. These 
new decentralized forms of electricity generation were heavily opposed by the incumbent energy providers. Nevertheless, local and urban initiatives were spreading. Energy providers initially were not attacking these small initiatives, because they were considered to be too small and unimportant, but they heavily opposed the promotion of renewable energy schemes on the political level and the development of a market framework that would enable the growth of these technologies.

A change in the composition of the federal government in the late 1990s nevertheless enabled new regulatory initiatives for renewables, which immediately had a tremendous effect [7]. Ambitious plans for the development of renewable energies in general and a contract for the gradual phase out of nuclear energy followed. In the years 2005 to 2008, the early movers were joined by a huge wave of local initiatives, which were animated by the success of renewable energies and their economic and social impact. After another change in the composition of the German federal government (2009), the framework within which the renewables were dynamically growing deteriorated and initially the planned phase out of nuclear power was postponed. Only after the Fukushima catastrophe (2011) the decision was again revoked, and political priorities now moved forward to an even quicker nuclear phase out. The German 'Energiewende', decision of 2011, however, somewhat happened in isolation. It was not accompanied by plans on how and whether the electricity system should in fact be transformed. The local, regional, and state governments engaged in planning changes to the electricity system felt strengthened, but the federal government and the incumbent energy providers actually tried to stem the wave of decentralization.

In order to understand the impact of these partially contradictory developments, one has to take a closer look at what specific actors actually aim to achieve with their initiatives and against what and whom and for what and whom they organize. To collect all these varying attempts under the umbrella of 'sustainability transition' does not do justice to the complexity of the developments and the varying lines of conflict between different actors.

At least the following forms of decentralized initiatives can be distinguished. At first, there are the aforementioned attempts by individuals or small groups of people experimenting with new forms of electricity generation and distribution. This movement went mainstream once; in the late 1990s, a regulatory framework for the development of renewable energies and the feed in of energy into the grid generated in a decentralized way was passed. The renaissance of this movement with different aims came about after 2009 when official energy prices soared and prices for self-generated energy declined. Now, it became economically interesting not to feed in self-generated electricity into the grid, but use it locally (and thus also bypassing the regulatory mess into which the law on regenerative energies meanwhile had degenerated).

Secondly, there are attempts especially by small communities to become $100 \%$ energy self-sufficient. This movement originally was also advanced by challenger groups, but meanwhile has attracted 'official' recognition, and federal as well as state programs for some years were supporting the development of respective energy plans.

Thirdly, the renegotiation of network concessions on a local and regional level has to be mentioned. In most cases, local and regional networks are run by the incumbent network operators. In order to be able to do this, they had been granted concessions by the respective local authorities. In the wake of the discussion about energy transitions, the process of granting concessions has been re-politicized. Against heavy opposition from the incumbent energy providers, some authorities try to give concessions to new partners. Between 2007 and 2012, approximately 190 ownership changes in electricity networks have been recorded, and 170 concessions for electricity and gas supply were not given to private companies but were granted to local authorities and local public companies. In Berlin, the city government tries to buy back the urban network (forestalling a public initiative with even more far-reaching aims), and in Hamburg, a citizen initiative forced the city government to negotiate a buyout of the incumbent energy provider against its will.

Fourthly, one of the partners getting a network concession might actually be an old partner. In the wake of the market liberalization, the old urban and local energy providers with some notable exceptions had lost their importance. Now, some of them are being re-vitalized (e.g., by competing for new concessions) or are newly founded. Since 2007, at least 60 new foundations of urban energy providers (a process that has by the way a strong regional flavor especially in Baden-Württemberg) were registered and 600 foundations of new energy cooperatives [23,24]. These developments show an interesting, sometimes confusing organizational mix. We can find wholly public as well as wholly private energy providers. Between these two poles, there is a mix of public-private partnerships with a varying mix of minority-majority shareholders. Gerstlberger [25] distinguishes three types of new urban energy providers with partnership constellations emerging in this phase: local privatizations with a participation of national or regional energy providers, international privatizations with a participation of an international energy provider, and privatizations with the participation of an investor which does not belong to the energy field proper. This mixture of organizational forms and the differentiation of actors render it difficult to detect an overall line of development with respect to, e.g., sustainability aims. However, this mixture is a clear indicator for a field in 
emergence, in which stable rules and best practices need yet to be established.

These developments should not only to be seen in the context that various actors for different reasons become interested in energy issues but also in the context of a roll back of the so-called 'New Public Management' movement. Not only in the field of energy a revitalization of the role of local governments can be observed. After disappointing experiences with privatizations, many entities are re-conceptualizing the role of local activities [26]. This refers both to sourcing back activities that had been previously outsourced to private actors as well as generally to a new legitimation for economic activities run by local governments. Energy questions in this respect are newly discovered as a legitimate and potentially economically profitable field of activities for local governments.

\section{Cases of $100 \%$ bio regions}

Given the scope and space limits of this article, we will not be able to analyze all the different types of local initiatives. We will instead focus on one clearly delineable sub-group, the so-called $100 \%$ bio regions, in which, nevertheless, all four mentioned types of decentralization can be found. These initiatives have as a common characteristic that they want to become independent from energy generated outside the respective region and intend to use only renewable energies for electricity generation. Insofar, they are following aims of sustainability. The first ideas were developed in the 1990s, and one decade later, the federal, state, and European money became available for the development of respective plans. The task of identifying $100 \%$ bio regions is made easier with the help of available directories and organizations representing these initiatives. Nevertheless, it is difficult to give a precise number of operating initiatives that have gone beyond setting up a plan and are implementing real changes. We know that there are spatial concentrations of these initiatives. One is in the northeastern state of MecklenburgVorpommern. In this economically peripheral area, the availability of public seed money for setting up plans was decisive. Another concentration is in the southwestern state of Baden-Württemberg. In this economically prospering region, the strong influence of an environmentally minded civil society and engaged citizens was decisive. Our empirical analysis concentrates on the initiatives in the south of Germany. The south of Germany can be characterized by economic prosperity, low unemployment, and firmly established institutions. Out of the available set of operating initiatives, we selected four cases for a detailed analysis, which exhibited a variance along two categories of special importance for our research. Based on an analysis of the aims stated by the organizers of the initiatives, we distinguished between aims that are oriented mainly towards inward energy production and those that are aiming at (also) exporting generated energy. All initiatives need to have a viable business plan (otherwise, no public money would have been available). They differ in the extent to which a profit orientation is prominent. This is also reflected in the type of organization that is being set up to implement the 100\% bio energy aims (profit vs. non-profit organization). Secondly, we considered it important to distinguish between initiatives which had been initiated and developed mainly by locals and initiatives in which outside actors play a dominant role.

The procedure of case selection in a formalized way thus was based on two observations. One refers to the definition of the population, the other to the selection of cases. The population of possible cases can be characterized as representative regions, which embodied the new paradigm of the energy transition $(100 \%$ renewable energy regions) with public funding. This means that the regions do represent a specific set of special conditions and social phenomena by the construction of specific governance structures underlying the goal to achieve an energy supply based on 100\% renewable energies [27]. The second argument provides the basis for the construction of a functional model. As it can be seen below, the model consists of four cases (regional fields) based on differences in the composition of the group of challenger actors assuming that specific structural and organizational designs will be influenced by the type of challenger actors to be found. The model aims to sample the maximum of variation and heterogeneity to understand how the phenomena can be seen with respect to different actor types. Let us take a look at the four cases.

Case 1: Region Hegau Bodensee, private actor. In this region, the goal of the energy transition had been advanced by Solarcomplex AG. The company works as an alternative municipal utility and aims to supply the Bodensee region with $100 \%$ renewable energies by the year 2030. The Solarcomplex AG invests, in particular, in solar energy and bioenergy villages. It acts as an institutional entrepreneur and was pioneering the development of business cases in the field of renewable energies. The framing of the initiative is characterized by stressing the economic potential of renewables ('growth by nature') and an emphasis on re-communalization. Since medium-sized cities are part of this region, urban utilities are newly created or revitalized. The region does not possess power plants of its own and is therefore up to $90 \%$ dependent on electricity coming from outside the region. Ten percent are domestic renewables (2013), mainly solar from individual sites, which are not owned or managed by Solarcomplex.

The company 'Solarcomplex' is interesting because it originated from a citizen action group, which later did spin out a private company, which eventually turned into a publicly listed company. It is, at the same time, 
profit oriented and determined to work for the political goal of $100 \%$ renewables and takes considerable risks in this gamble. Given the liberalized architecture of energy supply just as in the other cases, each community (or let us better say a significant proportion of households) within each serviceable part of the region needs to be persuaded to participate in the transition. Some local utilities have been coopted into the process but not all of them. This makes for a mixture of cooperation and conflict. The organizational forms chosen for the energy provision in the different communities differ. There are some general principles and technological priorities (biogas and biomass), but otherwise, the specific local constellation is taken under consideration.

Case 2: Region Neumarkt i.d. Oberpfalz, public-private actor. The regional management of the development concept for achieving a 100\% renewable energies supply is coordinated by the regional innovation agency Regina. It is run and supported by a host of actors from within and outside the region (e.g., Bavarian State Ministry for Economy, Infrastructure, Transportation and Technology; Bavarian Ministry for Food, Agriculture and Forests; Bavarian State Ministry for the Environment and Health; European Community; Sparkasse Neumarkt i.d.OPf.; and Banking Cooperative Neumarkt i.d.OPf.). The region follows the vision of a sustainable regional development, including the supply of $100 \%$ renewable energies.

Neumarkt is an example for a late-comer region and one whose plans have been advanced by politicians which essentially react to the incentives set by programs of the respective state (Bavaria), the federal government, and the European Union. Compared to the previous case with regard to governance structures, the administrative dominance is remarkable. Administrative units have been created and a special organization to further the case. The program framing stresses the issue of a sustainable regional development mirroring largely the official political statements from the state government.

Case 3: Region Hohenlohe-Odenwald-Tauber, Verband Abfallwirtschaftsgesellschaft des Neckar-Odenwald-Kreises $m b H(A W N)$, public actor. The concept of the Bioenergy Region Hohenlohe-Odenwald-Tauber was developed by an association called Abfallwirtschaftsgesellschaft NeckarOdenwald Kreis (AWN). It is a profit-oriented company $100 \%$ owned by regional public bodies. The region aims to become a zero-emission region by supporting the generation of renewable energies.

The origins of this initiative can be traced back to discussions about waste disposal. This is actually a trait, which is to be found in other initiatives as well. The search for new ways to dispose of waste not using landfills or building waste burning plants in the 1980s has led three communities to create a company charged with solving this problem. This company eventually thought about ways to turn waste into energy and gradually developed plans for a re-orientation of the energy supply system. This is a non-profit company, and the communities engaged in this project very strongly stress the issue of 'autarky'.

Case 4: Region Südschwarzwald, Südschwarzwald e.V. The key actor of the campaign Bioenergieregion Südschwarzwald plus is the association Südschwarzwald e.V. It has been set up by five counties. The campaign works for the expansion of bioenergy in the region with the objective of supporting municipalities and villages on the way towards becoming biomunicipalities and biovillages. It stresses the use of available biomass, which is supposed to bring in line available natural resources and social structures, as well as climate and environmental goals.

This is the initiative with the longest history, and at the same time, it is the most successful one. Its history can be traced back to a citizen initiative called 'Parents for a nuclear free future' (1986). It provided the nucleus for discussions about a new local energy supply system that would not need to rely on nuclear energy. For this purpose, the idea of a new local energy supplier was advanced. Respective plans were rejected by the sitting majority of the local council. The citizen action group nevertheless made this idea the central topic of the next local elections, and its supporters actually won a majority of the seats. They were immediately cancelling a contract with the incumbent energy provider. A citizen initiative could successfully stage a local referendum against this decision, but failed. Eventually, a green utility was formed, which soon began to work not only within the regional boundaries but also went beyond to spread the idea of electricity supply without nuclear energy. It merged with a vivid environmental movement in the area and various environmentally oriented networks. This has been a successful strategy, and an influential provider was established, which, however, for business reasons, looks highly critical on other decentralized initiatives in the region, which could damage their business prospects.

These four initiatives for some years have received public seed money, but they cannot be interpreted as regime projects. As the short historical sketches pointed out, the initiatives existed before they were 'officially' recognized and have aims that go beyond the funding cycle. The short sketches also demonstrated the idiosyncratic character of the initiatives and the broad mix of involved actors.

As mentioned, the cases are aligned along two dimensions (see Table 1). The first one being who was the driving actor in the development of the local initiative? We distinguish between an endogenous development in which the driving forces mainly come from inside the community and an exogenous development, in which the development was driven by actors from outside the 
Table 1 Cases and actor constellations

\begin{tabular}{lll}
\hline & Profit orientation & Public interest \\
\hline $\begin{array}{l}\text { External actor } \\
\text { involvement }\end{array}$ & Solarcomplex AG & $\begin{array}{l}\text { Regionale } \\
\text { Innovationsagentur } \\
\text { 'Regina' GmbH }\end{array}$ \\
$\begin{array}{l}\text { Endogenous } \\
\text { actors }\end{array}$ & $\begin{array}{l}\text { Abfallwirtschaftsgesellschaft } \\
\text { des Neckar-Odenwald- Kreises } \\
\mathrm{mbH}(\mathrm{AWN})\end{array}$ & \begin{tabular}{l} 
Südschwarzwald e.V. \\
\hline
\end{tabular} \\
\hline
\end{tabular}

community. Solarcomplex AG is an example of a private actor who actively addresses local communities and tries to convince them that to go renewables is a socially desirable as well as an economically feasible goal.

The pioneer local communities, however, have been usually been mobilized by endogenous actors. A typical case is the community with a newly elected mayor with 'green' credentials, who had good personal connections to experts in the field of renewables. In our case, a bioenergy pioneer, who later on founded a related company, was living in the same community as the mayor. The two of them convinced the local council and later on a majority of the population that the community should go 'bio'. Initially, this could be done without much external interference or help.

A second line of distinction separates cases in which the economic motive is dominating from those in which the profit orientation is secondary or ruled out by the organizational form chosen by the community to reorganize energy supply (e.g., registered association). The economic viability of all projects with a financial contribution of local budgets has to be guaranteed, nevertheless. Otherwise, upper-level control units could derail the projects easily. But it is a decisive distinction whether the community looks upon the projects as a means to provide new profits, especially by exporting not needed energy to other communities or the grid, or not.

External actors usually have a more or less clear idea about how activities among the main actors involved in the initiatives shall be coordinated. Solarcomplex AG as well as ministries has a blueprint that is adapted to local conditions and therefore is still to a certain extent idiosyncratic, but nevertheless clearly recognizable and 'stable'. Initiatives advanced by endogenous actors show a greater variance in their governance setup and might change this setup more easily over time. The aforementioned example of the green mayor is linked with a story from an initial concentration on bioenergy, which was replaced by a failed attempt to switch to wind power and finally a massive installation of solar panels with differing coalitions and organizations being established to pursue the green goals. This last example also shows that the choice of technologies and the development of technology mixes are dependent on local conditions and contingent power constellations.

\section{Lines of conflict}

Without a consideration of the sources of potential opposition, we cannot assess the effectiveness of the attempts towards field change. Generally, institutional resilience is liable to damage the chances for change. Resilience, however, is a variable, and its effects may be to channel rather than simply to obstruct change. The conflict with the incumbent actors is usually not a zero-sum game. The incumbents at the beginning will try to oppose any change, but long-term mobilization efforts will also lead to attempts towards cooptation or building coalitions with the challengers. What are the main lines of conflict between actors who want to reorganize and the incumbents around which the battle for reorganization is waged in our cases and more generally for decentralization initiatives?

Electricity networks constituting something like a natural monopoly on the local and regional level are administered by energy providers, which have been granted concessions by the responsible public authority. These providers eventually may also own the physical network infrastructure. If local authorities want to buy back the concessions, cancel the concessions or revoke them, they usually face heavy resistance from the incumbent actors as could be seen in our cases. They are offering sticks (courts, high prices and costs, refusal to hand over data, etc.) and some carrots (higher fees, more participation, etc.). Very often, the network operators are linked to specific political actors in the community, which immediately politicizes the conflict. In many cases cross ownership problems play an important role. Local communities can be among the 'owners' of the big energy providers (in the same way as new green providers can also be community owned). Insofar, they should have an interest in their well-being since the energy providers (at least in the golden days of the past) provided a steady flow of income to the local communities. In addition, since the system of electricity supply is highly politicized, many (former) politicians are employees or even managers of the incumbent energy providers. Insofar, it is no wonder that one important line of conflict always centers around the relationship between local communities and the big energy providers.

In our bioenergy case, the new local network operator was forced to sell his business back to the dominant network operator. Due to the growing local electricity production, the increasing interconnection problems with the grid, and steadily increasing regulatory requirements, it could not any longer fulfill its role and the fastest and easiest way out was to sell back. The energy provider promised not to unravel the local energy system, which did get various prizes for being outstanding, but the initial contacts also demonstrated clearly that it is in this business for different reasons than the local community.

An expertise for the German parliament enumerated the strategies used by the incumbent energy providers to 
prevent local communities from looking for new partners. In spite of the fact that there are regulations that fix the prizes that have to be paid for regaining control over the network infrastructure, the energy providers routinely demand too high prices. Smaller communities lag the expertise necessary to counter these evaluations and are avoiding lengthy and potentially costly juristic struggles. Another method is to prolong the bargaining. Regulations now say that if no compromise can be found within a year after the concession has been cancelled, the old network operator can operate the network without having to pay a concession fee. Furthermore, the incumbent network operators can try to avoid communicating data that are necessary for running the network and/or establishing its actual worth. There have also been cases were manipulated data have been handed over. Threatening court action, withdrawal of sponsorships for sports and cultural activities, and firing personnel from the community are some other methods used by incumbents ${ }^{\mathrm{d}}$.

The relationship between communities and energy providers also has an infrastructure component reaching beyond the limits of the community. Neither at the beginning of the transition nor later on local communities will be able to do without a connection to the general grid. The justification may be the dominance of volatile energy sources (wind and solar) or the necessity to have a backup if local or regional energy resources do not work according to plan. One of the bio-communities managed by Solarcomplex produces more electricity than it needs by itself. Nevertheless, at the moment, it is dependent for a continuous electricity supply on its connection to the overall grid. The reason in this case is that due to the lack of affordable energy storage technologies, the electricity generated cannot be used at the time when it is most needed, but only at the time when it is produced. This might change from medium to long term due to technological developments, but it constitutes a significant problem for many local communities. Furthermore, plans are discussed by the federal government and propagated by the energy providers to charge the connection to the grid instead of the amount of electricity actually used. This would disadvantage local communities and make their efforts more costly.

These conflicts between challengers and incumbents were present in all cases examined. The intensity of the conflict varied. An important balancing role is played by old local network operators or local energy providers, which can shift allegiances and can leave the coalition with the potentially losing incumbent to enter coalitions with a new one consisting of local actors.

In order to be able to build up opposition to the incumbent actors, the challengers need to mobilize ordinary citizens. A change in the system of electricity supply involves that citizens cancel existing contracts, sign new ones with a hitherto unproven organization, and often take up liabilities of their own (in the form of credits, buying new equipment, etc.). This is no easy feat. Theoretically speaking, the existing system of electricity supply has solved coordination problems both for consumers and regulators. This can be considered to be an equilibrium, and once actors have coordinated on one, they have little incentive to alter their behavior. Solarcomplex AG demanded in one case studied that $60 \%$ of the local households switch provider before they would even start building a new installation. The formidable difficulties involved in coordinating multiple actors around some possible institutional alternative hamper the prospects for revision. This is especially so, since the established system of electricity supply does not pose tangible problems (e.g., in the form of blackouts).

The mobilizers in all cases analyzed try to overcome this problem by blending the general issue of climate change and sustainability with elements of regional selfsufficiency and regional pride. The dominating narratives are 'we are doing something about the environment' and 'we are strengthening our community'. This also implies that in many cases, a reflection in what direction the community should develop soon follows. Within the communities, resistance against such plans regularly comes from farmers, at least from parts of the farming population. The support of famers in most cases is necessary because their land is needed for various purposes. On the other hand, there are farmers who feel threatened by these developments. They fear an increase of the rent for the land they use for agricultural purposes and are feeling uneasy or are even envious towards a new breed of energy farmers who seem to earn money for doing nothing.

\section{Conclusion}

The German federal government has stated that up until $2050,80 \%$ of the electricity consumed shall come from renewable energies. At the moment, the contribution of renewables is slightly above $25 \%$. Existing plans do not spell out how and by who with what technologies this political aim is supposed to be achieved. Our paper started with the assumption that cities and local and regional communities are at the forefront of efforts to change the electricity supply system in Germany [28]. Long before the government has made its decision, citizen action groups, NGOs, and local political action groups have become active organizing to achieve the 'energy transition'. It is widely acknowledged that if the government sticks to its aims, not only nuclear power plants but also other conventional power plants (coal and gas) will have to be shut down and replaced by smaller more dispersed entities of power generation. Decentralization in this context is not only a technological question but also a broader socio-technical one related to emergent 
governance structures. Will the electricity system of the future be run by the same actors as the present one, following broadly the same strategic imperatives, or will it be run by new actors like local coalitions, investment funds, and new field entrants?

We are assuming that spatial, context specific factors are important for understanding the development and eventual shape of local initiatives. We have claimed that initiatives are advanced by a heterogeneous group of actors, with varying aims, which take under consideration local power constellations, spatial conditions, and the existing set of technological options. Insofar, spatial elements (of a social as well as ecological nature), political conditions, economic structures, settlement profiles, and available material resources (wind, sun, wood, and biomass) matter. In the present phase of the energy transition, we are able to observe a kind of division of labor in the sense of a space-specific specialization of innovation profiles (e.g., solar cities, bio-energy regions, and energy services region).

There still remains a wide array of open empirical and analytical questions, however, that need to be addressed. Most local initiatives face a difficult time at the moment, and it will be interesting to see whether specific institutionaland/or actor-related characteristics can contribute to the resilience of energy initiatives. We found that local initiatives vary greatly in the technological mixes they are choosing, the way they organize, the organizations they eventually setup, and the measures they employ. We gather that the variety of ensuing governance configurations will decrease over time, either (a) because the regulatory framework under discussion at the federal level will require certain adjustments, (b) because certain local realizations become considered as success cases and will therefore be imitated by others, and (c) as Hargreaves et al. [21] have established, because intermediaries play an increasing role in the process, which will lead to a professionalization and supposedly homogenization of practices.

It also remains an open question whether the local initiatives can hang on to their role as challengers to the old system and lead the way towards a new electricity system. At the moment, the incumbents, supported by the federal government, are reorganizing and are attempting to integrate initiatives towards mainly technical decentralization under a new centralized management with the local initiatives fulfilling roles of decentralized energy generation within a pre-determined framework that will give them only a little space to maneuver. This would change the transition path from one being mostly emergent to one being managed. The incumbent actors still dominate the electricity supply sector, they own power plants and network concessions, they are well organized, and they have well-established connections to the field of politics and power. The local initiatives on the other hand have little common interests and are, by far, less well organized and especially since the demise of the red-green coalition on the federal level has lost direct access to political decisionmaking circles. On the other hand, they still can rely on a broad general public sentiment in favor of renewables and against the old incumbents.

We suggest that in order to avoid the concentration of the analysis on one or only a few cases, the theory of strategic action fields could be of benefit in order to reach results that are more generic. It directs our attention to the social structure of fields, the dominant actors, and strategies and forms of organization chosen, as well as the dominant lines of conflict. Given the diversity of actors involved, strategies developed, and organizational forms established, we could definitely talk about an emergent field that is not yet stabilized. Insofar, it is also very difficult to say which of the analyzed initiatives at the end will survive and what influence they will have on the overall transition of the energy system and the specific sustainability pathway. Theoretically, there seems to be a limited set of possible outcomes of a transition process. Option one would be for the incumbent actors to survive based on new coalitions they are engaged in, cooptation, and political support. Option two would be a differentiation of the field like we had in the period between 1999 and approximately 2008, when two parallel institutions, one for renewable energies and one for conventional energies, were developed in parallel. Political attempts at present aiming to create a new common regulatory framework for all types of energy sources seem to make this solution not very probable. We could also face a continuing period of insecurity. In other words, a prolongation of the present situation in which all actors are demanding more straightforward and clear decisions by the government which do not come forward, however. Furthermore, we could experience a wholesale transformation of the field. The eventual outcome is unclear, but it is obvious that local initiatives have played and still will play a pioneering role for the energy transition in Germany.

\section{Endnotes}

an the following, we will make no distinction between local, urban, and regional attempts towards developing plans for energy transitions. The decentralized character of these initiatives, which put them into opposition to the dominating centralized architecture, is the most important common element for the purposes of this study.

${ }^{\mathrm{b}}$ The article is based on preliminary empirical results from two ongoing projects. One is financed by the Helmholtz Association and the state government of Baden-Württemberg, the second one is funded by the German Federal Ministry for Research and Education (FONA-program). 
${ }^{\mathrm{c}}$ The argument that regime actors might deliberately weaken the regime in which they are the incumbent actor begs the question why they should do this.

${ }^{\mathrm{d}}$ For a comprehensive overview and evaluation, see [29].

\section{Competing interests}

The authors declare that they have no competing interests.

\section{Authors' contributions}

$\mathrm{NH}$ was mainly responsible for the empirical research on which the paper is based. GF provided the conceptual framework and the theoretical considerations. Both authors read and approved the final manuscript.

Received: 22 October 2013 Accepted: 25 June 2014

Published: 29 July 2014

\section{References}

1. Joss S (2011) Eco-city governance: a case study of Treasure Island and Sonoma mountain village. J Environ Pol Plann 13(4):331-348

2. Fligstein N, McAdam D (2011) Toward a general theory of strategic action fields. Sociol Theory 29(1):1-26

3. Fligstein N, McAdam D (2012) A theory of fields. Oxford University Press, Oxford

4. Geels FW (2013) Politics and power in low-carbon electricity transitions: a multi-level analysis of green niche-innovations and resilient regimes. In: Tyfield D, Urry J (eds) Theory, culture and society. SAGE, Thousand Oaks

5. Hodson M, Marvin S (2010) Can cities shape socio-technical transitions and how would we know if they were? Res Pol 39(4):477-485

6. Bulkeley H, Broto VC, Hodson M, Marvin S (2011) Cities and low carbon transitions. Routledge, Oxon

7. Fuchs G, Wassermann S (2012) From niche to mass markets in high technology: the case of photovoltaics in Germany. In: Bauer JM, Lang A, Schneider V (eds) Innovation policy and governance in high-tech industries. Springer, Berlin

8. Geels FW, Verbong G (2007) The ongoing energy transition: lessons from a socio-technical, multi-level analysis of the Dutch electricity system (1960-2004). Energy Policy 35:1025-1037

9. Geels FW (2005) Co-evolution of technology and society: the transition in water supply and personal hygiene in the Netherlands (1850-1930) — a case study in multi-level perspective. Tech Soc 27(3):363-397

10. Geels FW (2010) Ontologies, socio-technical transitions (to sustainability), and the multi-level perspective. Res Pol 39(4):495-510

11. Elzen B, Geels FW, Green K (2004) System innovation and the transition to sustainability: theory, evidence and policy. Edward Elgar, Cheltenham

12. Raven R, Verbong G (2010) Multi-regime interactions in the Dutch energy sector: the case of combined heat and power technologies in the Netherlands. Technol Anal Strat Manag 19(4):1970-2000

13. Rip A, Kemp R (1998) Technological Change. In: Rayner S, Malone EL (eds) Human choice and climate change, vol 2. Battelle, Columbus

14. Markard J, Truffer B (2008) Technological innovation systems and the multilevel perspective: towards an integrated framework. Res Pol 37:596-615

15. Kemp R, Rip A, Schot J (2001) Constructing transition paths through the management of niches. In: Garud R, Karnøe P (eds) Path dependence and creation. Lawrence Erlbaum, Mahwah

16. Monstadt J (2009) Conceptualizing the political ecology of urban infrastructures: insights from technology and urban studies. Environ Plann A 41(8):1924-1942

17. Burch S (2011) Sustainable developments paths: investigating the roots of local policy responses to climate change. Sustain Dev 19:176-188

18. Smith A, Stirling A, Berkhout F (2005) The governance of sustainable sociotechnical transitions. Res Pol 34(10):1491-1510

19. Scharpf FW (2000) Interaktionsformen. Akteurzentrierter institutionalismus in der politikforschung. Leske und Budrich, Leske

20. Quitzau MB, Jense JS, Elle M, Hoffmann B (2013) Sustainable urban regime adjustments. J Cleaner Prod 50:140-147

21. Hargreaves T, Hielscher S, Seyfab G, Smith A (2013) Grassroots innovations in community energy: the role intermediaries in niche development. Global Environmental Change 23(5):868-880, doi:10.1016/j.gloenchva.2013.02.008
22. REN21 (2013) Renewables 2013 global status report. REN21 Secretariat, Paris

23. Aden $\mathrm{H}$ (2010) So eine Chance hat man nur alle 20 Jahre. Vom auslaufenden Konzessionsvertrag zum Relaunch der Stadtwerke. In: AKP. Fachzeitschrift für alternative Kommunalpolitik (April). AKP, Bielefeld, pp 46-48

24. Libbe J, Köhler H, Beckmann KJ (2011) Infrastruktur und stadtentwicklung. Technische und soziale infrastrukturen - herausforderungen und handlungsoptionen für infrastruktur- und stadtplanung. Springer, Heidelberg

25. Gerstlberger W (2009) Zwei jahrzehnte privatisierung in Deutschen kommunen -herausforderungen und argumente für den erhalt der stadtwerke WISO direkt (Mai). Friedrich Ebert Stiftung, Berlin, pp 1-4

26. Libbe J (2013) Rekommunalisierung in Deutschland - eine empirische bestandsaufnahme. In: Matecki C, Schulten T (eds) Zurück zur öffentlichen hand? VS, Hamburg

27. Bradshaw Y, Wallace M (1991) Informing generality and explaining uniqueness: the place of case studies in comparative research. Int J Comp Sociol 32(1-2):154-171

28. Morlet C, Keirstead J (2013) A comparative analysis of urban energy governance in four European cities. Energy Policy 61:852-863

29. Berlo K, Wagner O (2013) Auslaufende Konzessionsverträge für Stromnetze. Strategien überregionaler Energieversorgungsunternehmen zur Besitzstandswahrung auf der Verteilnetzebene. Wuppertal Institut für Klima, Umwelt, Energie GmbH, Wuppertal

doi:10.1186/s13705-014-0016-6

Cite this article as: Fuchs and Hinderer: Situative governance and energy transitions in a spatial context: case studies from Germany. Energy, Sustainability and Society 2014 4:16.

\section{Submit your manuscript to a SpringerOpen ${ }^{\odot}$ journal and benefit from:}

- Convenient online submission

Rigorous peer review

- Immediate publication on acceptance

- Open access: articles freely available online

- High visibility within the field

- Retaining the copyright to your article

Submit your next manuscript at $\gg$ springeropen.com 